\title{
IODP Expedition 327 and Atlantis Expedition AT 18-07: Observatories and Experiments on the Eastern Flank of the Juan de Fuca Ridge
}

\author{
by Andrew T. Fisher, Takeshi Tsuji, Katerina Petronotis, C. Geoff Wheat, \\ Keir Becker, Jordan F. Clark, James Cowen, Katrina Edwards, \\ Hans Jannasch, and the IODP Expedition 327 and \\ Atlantis Expedition AT18-07 Shipboard Parties
} doi:10.2204/iodp.sd.13.01.2011

\begin{abstract}
Integrated Ocean Drilling Program (IODP) Expedition 327 (summer 2010) was designed to resolve the nature of fluid-rock interactions in young, upper volcanic crust on the eastern flank of the Juan de Fuca Ridge. Expedition 327 drilled, cased and cored two new basement holes, conducted hydrogeologic experiments, and installed subseafloor borehole observatories (Circulation Obviation Retrofit Kits, CORKs). These CORKs were intended to allow borehole conditions to recover to a more natural state after the dissipation of disturbances caused by drilling, casing, and other operations; provide a long-term monitoring and sampling presence for determining fluid pressure, temperature, composition, and microbiology; and facilitate the completion of active experiments to resolve crustal hydrogeologic conditions and processes. Expedition 327 was followed (summer 2011) by R/V Atlantis Expedition AT18-07, with the remotely-operated vehicle (ROV) Jason, to service these CORKs, collect subseafloor pressure data, recover and deploy autonomous fluid and microbial samplers, collect large volumes of borehole fluids, and initiate a cross-hole hydrogeologic experiment using an electromagnetic flow meter. In addition, Atlantis Expedition AT18-07 refurbished an old CORK that could not be replaced during IODP Expedition 327, completing a critical part of the three-dimensional observation network that is currently being used to monitor a large-scale, directional formation response to long-term fluid flow from the crust.
\end{abstract}

\section{Introduction and Goals}

Fluid flow within volcanic ocean crust influences the thermal and chemical evolution of oceanic lithosphere and lithospheric fluids; subseafloor microbial ecosystems; diagenetic, seismic, and magmatic activity along plate-boundary faults; and the creation of ore deposits on and below the seafloor (Coggon et al., 2010; Huber et al., 2006; Parsons and Sclater, 1977). The global hydrothermal fluid mass flux through the upper oceanic crust rivals the global riverine fluid flux to the ocean, passing the volume of the oceans through the crust once every $10^{5}-10^{6} \mathrm{y}$ (Johnson and Pruis, 2003; Mottl, 2003; Wheat et al., 2003). Most of this flow occurs at relatively low temperatures, far from volcanically active seafloor-spreading centers where new ocean floor is created. This "ridge flank" circulation can be influenced by off-axis volcanic or tectonic activity but is driven mainly by the flow of lithospheric heat from below the crust.

Despite the importance of fluid-rock interactions in the crust, little is known about the magnitude and distribution of critical hydrologic properties; the rates and spatial extent of ridge-flank fluid circulation; the extent to which crustal compartments are well connected or isolated (laterally and with depth); or the links between ridge-flank circulation, crustal alteration, and geomicrobial processes. IODP Expedition 327 (Fisher, et al., 2011b) was part of a long-term experimental program that has included multiple survey, drilling, submersible, and ROV expeditions; observatory and laboratory testing, sampling, and monitoring; and modeling of coupled fluid-thermal-chemical-microbial processes. Expedition 327 built from the technical and scientific achievements and lessons learned during Ocean Drilling Program (ODP) Leg 168 (Davis et al., 1997), which focused on hydrothermal processes within uppermost basement rocks and sediments along an age transect, and IODP Expedition 301 (Fisher et al., 2005a), which penetrated deeper into the crust at the eastern end of the Leg 168 transect (Fig. 1). During both expeditions, CORKs were installed in basement holes to allow borehole conditions to recover to a more natural state after the dissipation of disturbances caused by drilling, casing, and other operations; to provide a long-term monitoring and sampling presence for determining fluid pressure, temperature, composition, and microbiology; and to facilitate the completion of active experiments to resolve crustal hydrogeologic conditions and processes (Fisher et al., 2005b, 2011c; Orcutt et al., 2010b; Wheat et al., in review). During subsequent ROV and submersible expeditions, borehole pressure and thermal data were collected, fluid and microbial samples were recovered, batteries, data loggers, and sampling systems were replaced, and long-term, cross-hole experiments were initiated.

We present operational results from IODP Expedition 327, which sailed on the $\mathrm{D} / \mathrm{V}$ JOIDES Resolution, and $\mathrm{R} / \mathrm{V}$ Atlantis and ROV Jason expedition AT18-07 (completed in 2011), focusing on the installation and use of CORKs. Data and samples gathered during the second expedition show that newly-installed CORKs are working as intended, and the ambitious monitoring and cross-hole experimental goals that motivated these experiments are being achieved. 


\section{Experimental Setting and Selected Earlier Work}

Many studies have summarized geology, geophysics, basement-fluid composition, and hydrogeology within young seafloor on the eastern flank of the Juan de Fuca Ridge (Fig. 1; Davis et al., 1992; Elderfield et al., 1999; Hutnak et al., 2006; Wheat et al., 2000). Topographic relief associated with the Juan de Fuca Ridge axis and abyssal hill bathymetry on the ridge flank has helped trap turbidites flowing west from the continental margin (Underwood et al., 2005), resulting in the rapid burial of young oceanic basement rocks. Sediment cover is regionally thicker and more continuous towards the continental margin, but there are basement outcrops north and south of the Expedition 327 work area, up to $100 \mathrm{~km}$ east of the spreading center.

During ODP Leg 168, a transect of eight sites was drilled across 0.9-3.6 Ma seafloor; sediment, rock, and fluid samples were collected; thermal, geochemical, and hydrogeo-

logic conditions in basement were determined; and CORKs were installed in the uppermost crust (Davis et al., 1997). Two of the Leg 168 observatories were placed in 3.5-3.6 Ma seafloor in Holes $1026 \mathrm{~B}$ and $1027 \mathrm{C}$, near the eastern end of the drilling transect (Fig. 1). IODP Expedition 301 returned to this area and drilled deeper into basement; sampled additional sediment, basalt, and microbiological materials; replaced the borehole observatory in Hole 1026B; and established two additional CORK observatories at Site U1301 (Fisher et al., 2005a).

Before Leg 168 there was a largely two-dimensional view of the dominant fluid circulation pathways in this area, with recharge thought to occur close to the ridge where basement was exposed (near the western end of the Leg 168 transect), and flowing toward the east. Some results from Leg 168 were consistent with this view, including seafloor heat flow and basement temperatures that increase and basement fluids that are warmer and more altered with progression from west to east (Davis et al., 1999; Elderfield et al., 1999; Stein and Fisher, 2003). However, Leg 168 results and related surveys showed that ridge-parallel fluid transport is important in this region. For example, although basement fluids are 
warmer and older with increasing distance from the ridge along the western end of the drilling transect, fluids are younger with respect to ${ }^{14} \mathrm{C}$ at additional Leg 168 sites to the east, although the eastern fluids are also warmer and more altered (Elderfield et al., 1999; Walker et al., 2007). Bathymetric data from near the western end of the Leg 168 transect show exposed basement north and south of the drill sites, which may allow hydrothermal fluids to recharge and discharge (Hutnak et al., 2006). Heat flow data from this area support this interpretation, as do geochemical and thermal data from the eastern end of the Leg 168 transect (Fisher et al., 2003; Wheat et al., 2000). Numerical models of outcrop-to-outcrop hydrothermal circulation between recharging and discharging seamounts show that rapid flow can be sustained (as a "hydrothermal siphon") and basement temperatures matched to observations if basement permeability along the flow path is about $10^{-11} \mathrm{~m}^{2}$ (Hutnak et al., 2006).

Hydrologic (packer) experiments conducted in upper basement during Expedition 301 indicate a layered crustal structure with permeability on the order of $10^{-12}-10^{-11} \mathrm{~m}^{2}$ (Becker and Fisher, 2008). Fisher et al. (2008) conducted additional hydrogeologic analyses using the formation pressure response to the long-term flow of cold bottom seawater into basement at Site U1301 in the thirteen months after drilling, as observed at Site 1027 (2.4 km away). Their data suggest large-scale permeability at the low end of or below values indicated by single-hole packer testing. This result was unexpected because cross-hole tests should be representative of a much larger crustal volume than single-hole tests, yielding higher apparent permeability values. One possible explanation is that basement permeability is azimuthally anisotropic, a hypothesis that is being tested with Expedition 327 CORKs (as described below).

CORKs installed in this area during ODP Leg 168 and IODP Expedition 301 have produced valuable fluid and microbial samples indicating the nature of linked geochemical and microbiological conditions in basement (Cowen et al., 2003; Orcutt et al., 2010a; Smith et al., in review; Wheat et al., 2004a, 2010). Cells collected from the Hole 1026B wellhead included bacteria and archaea whose closest known phylogenetic neighbors comprise nitrate reducers, thermophilic sulfate reducers, and thermophilic fermentative het-erotrophs. Fluid and microbial samples collected at depth in Holes 1026B and Hole U1301A indicate strongly reducing conditions within basement once recovery to a pre-drilling geochemical state was achieved, and with colonization of incubation substrate by the thermophilic anerobe Fermicutes and mesophilic oligotrophs. The highest cell counts within flow-through experiments from Hole U1301A were found on samples of olivine, and culturable organisms from these samples were capable of nitrate reduction and iron oxidation. Expedition 327 CORKs should provide even better samples of endemic microbial communities from the crust, as newer observatories were designed (a) to reduce the extent of contamination (by using inert materials where possible and coating reactive materials with nonreactive coatings) and (b) to simplify and speed the extraction of large quantities of fluid (using larger diameter tubing and custom fittings).

\section{IODP Expedition 327}

The primary goals of Expedition 327 were (1) to drill two new basement holes at Site U1362, core and wireline log one of these holes, run and initiate hydrogeologic tests, and install CORK observatories; (2) to recover an existing CORK from Hole $1027 \mathrm{C}$, deepen the hole and install a new CORK; and (3) to recover and replace an instrument string deployed in the CORK in Hole U1301B (Fisher, et al., 2011b). Secondary objectives included sampling and analyzing sediments and pore fluids near an area of suspected hydrothermal recharge to assess patterns and rates of ridge-flank hydrothermal circulation in basement.

Holes U1362A and U1362B were drilled and cased through the upper $\sim 100 \mathrm{~m}$ of basement, without coring, in order to avoid unstable layers and to allow greater depth penetration into the crust (Fig. 2a). Hole U1362A was drilled and cored to 528 meters below seafloor (mbsf), 292 meters sub-basement, $200 \mathrm{~m}$ south of Hole 1026B (Fig. 1). Core recovery was $\sim 30 \%$, typical for upper crustal rocks, and eight lithologic units were identified. Numerous samples were collected for post-expedition petrologic, alteration, physical properties, and microbiological analyses. A single wireline logging string helped to determine formation prop-erties and to identify suitable intervals for hydrologic testing and CORK installation. Caliper logs revealed an enlarged borehole over most of the open interval, but there were several near-gauge sections generally corresponding to intervals that produced good core recovery and/or drilled slowly. Short-term packer experiments were completed at depth in Hole U1362A to assess permeability adjacent to the borehole, with hourly injection and recovery periods.

Hole U1362B was drilled to 359 mbsf (117 meters subbasement), $300 \mathrm{~m}$ south of Hole U1362A and $500 \mathrm{~m}$ north of Hole U1301B (Fig. 1). A 24-h pumping and tracer injection experiment was initiated prior to CORK installation in this hole (Fisher et al., 2011a). Pressure gauges and fast-sampling reverse osmotic pumps were run in a specially designed "stinger" that extended into the open hole just below the base of casing, which was sealed with a casing running tool. During this experiment, seawater was pumped into the formation at $\sim 7 \mathrm{~L} \mathrm{~s}^{-1}$. Tracers added during pumping included $\mathrm{SF}_{6}$ gas (injected continuously for $\sim 22 \mathrm{~h}$ ), $\mathrm{CsCl}$ and $\mathrm{ErCl}_{3}$ salts (during a brief period $3 \mathrm{~h}$ into the experiment) and $\mathrm{CsCl}$ and $\mathrm{HoCl}_{3}$ salts (at $19 \mathrm{~h}$ ), fluorescent microspheres (at $20 \mathrm{~h}$ ), and stained bacteria (at $21 \mathrm{~h}$ ) extracted from sea-surface water. Fresh water was pumped rather than seawater during two, hour-long periods. Evaluation of tracer transport in the 


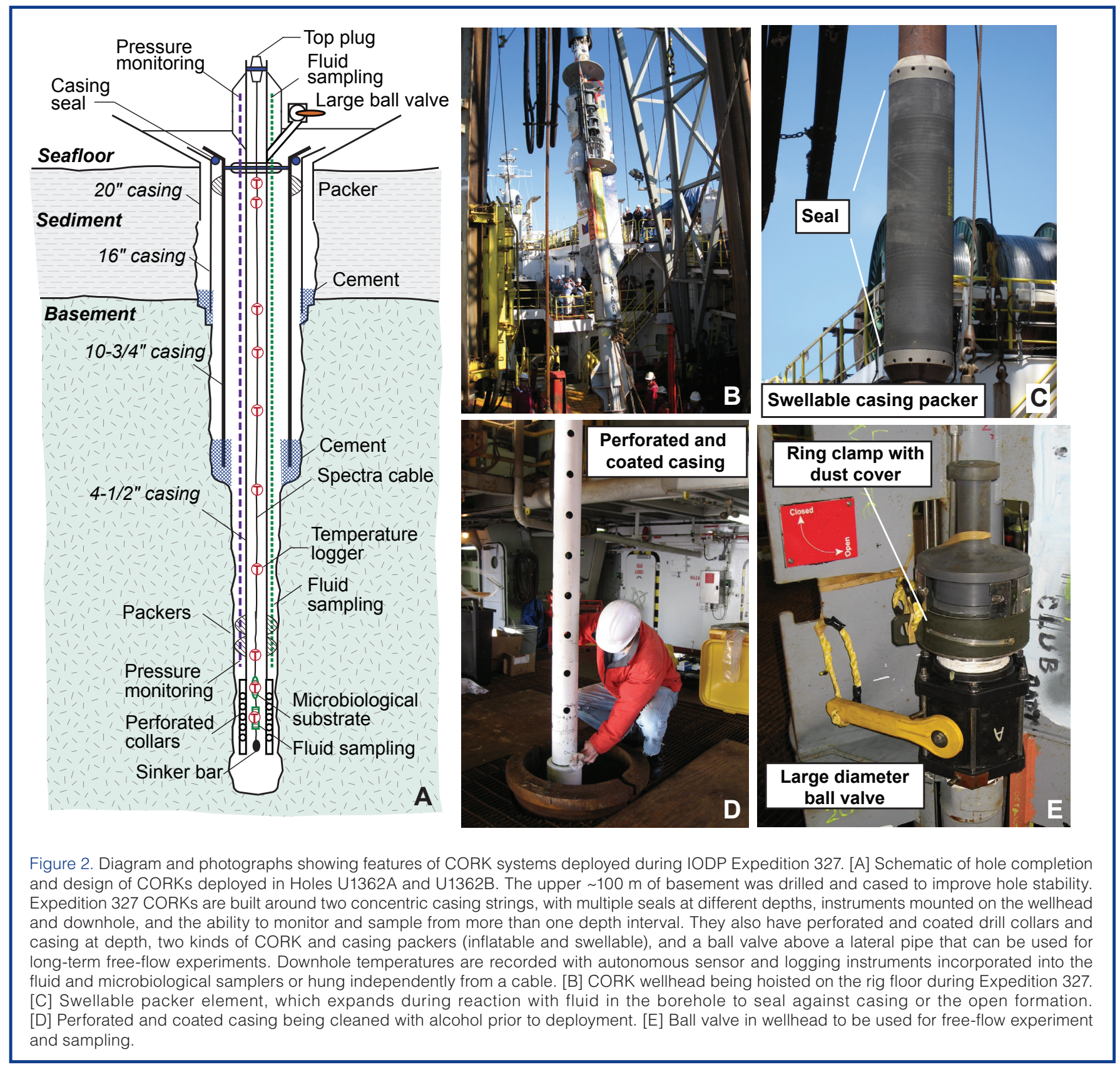

crust will require recovery of borehole samplers from nearby CORKs, as discussed below.

The CORK systems deployed during Expedition 327 to isolate and allow monitoring and sampling of basement fluids and microbes include multiple types of casing and borehole seals (Fig. 2a). The part of the CORK that sits above the seafloor when installed-referred to as the "wellhead"-is constructed from concentric 41/2-inch and 103/4-inch casing sections, with parts of the larger casing omitted or cut away between horizontally oriented bulkheads (Fig. 2b). Seafloor sampling and valve manifolds, sensor packages, data loggers, and samplers offset by $120^{\circ}$ are arranged within three bays, and separated by vertical gussets. The gussets provide strength to the wellhead, help to guide the ship's camera system and the submersible platform around the bays during CORK installation, and serve as submersible and ROV hand- holds for stability and leverage. For each of the Expedition 327 CORKs, one bay is dedicated to monitoring and logging pressure data, another is configured for fluid sampling, and a third designed to house a flowmeter and permit microbiological sampling and other experiments.

Expedition 327 CORKs use two kinds of packers to isolate one or more borehole intervals: hydraulic (inflatable) and swellable packers (Fig. 2c). Inflatable packer elements provide an immediate seal, but their long-term reliability is unknown. Swellable elements react with seawater and expand over several months, and should provide a seal that lasts for years. The lower parts of these CORKs (extending down from the base of the lowermost set of packers) are extensively coated with non-reactive materials (Fig. 2d). Perforated and coated casing and drill collars in these CORKs house downhole instruments (fluid samplers, tem- 
perature sensors, microbiological growth substrate) that remain in good communication with the surrounding fluids and rocks and are protected from collapse of unstable formation (ensuring future recovery). The Expedition 327 CORKs also have a pipe that comes off the central casing near the wellhead, ending with a ball valve and ring clamp (Fig. 2e). Opening this valve allows overpressured formation fluids to flow from the wellhead without having to remove the top plug. These fluids can be sampled and the rate of flow from the CORK measured, as described below.
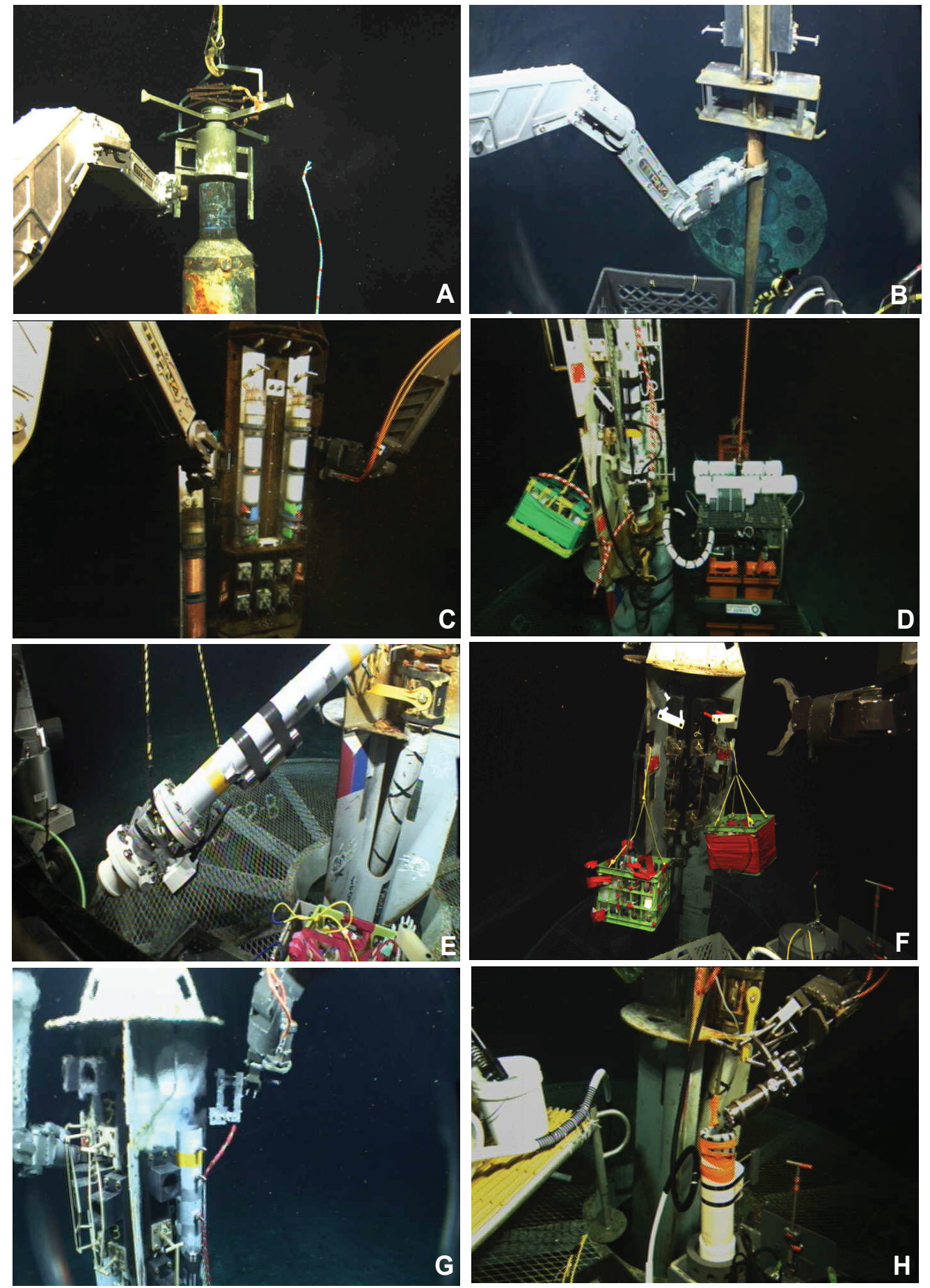

Figure 3. Photographs of CORK servicing activities during Expedition AT18-07. [A] Top Hat Extraction Tool deployed on old CORK wellhead in Hole 1027C. This tool is being used to remove an old electrical connector that was corroded in place, blocking access to the data logger. [B] Manifold insert being carried to CORK in Hole 1027C after removal of old connector and data logger. This tool has valves and fitting for pressure monitoring and a large ball valve and ring clamp (Fig. 2e) that can be used for later instrument deployments. [C] Exchanging OsmoSamplers on CORK in Hole U1301B. Samplers are (left to right): copper (gas tight), geochemistry (Teflon), microbiology. [D] OsmoSamplers in milk crate and GeoMICROBE sled deployed on ROV platform in Hole U1362B. [E] Flowmeter being lifted for deployment on Hole U1362B. [F] Multiple OsmoSampler crates deployed on CORK in Hole U1362A. [G] Fluid sampling inlet being deployed at top of chimney discharging shimmering hydrothermal fluids on Hole U1362B. [H] Gas-tight sampler being used with gas trap to collect fluids from Hole U1362A.
The Hole U1362A CORK was configured to monitor two basement intervals. Pressure in both intervals is monitored through stainless steel tubing connected to mini-screens installed just below inflatable packers at the top of distinct crustal intervals. Stainless steel fluid sampling lines terminate at two depths. A single polytetrafluoroethylene (PTFE) microbiological sampling line ends in a titanium mini-screen. The downhole instrument string includes six OsmoSamplers and microbial growth incubators positioned within coated and perforated casing and collars, and eleven autonomous tem-perature probes.

The Hole U1362B CORK monitors a single basement interval that extends $\sim 75 \mathrm{~m}$ below swellable and inflatable packers positioned just inside the base of casing. Pressure is monitored continuously in this basement interval and also in the cased interval above to assess the quality of hydraulic sealing of this observatory. This CORK also contains stainless steel fluid sampling lines and a dedicated PTFE microbiological sampling line. The downhole instrument string comprises six OsmoSamplers, and microbial growth incubators and eight autonomous temperature probes, including two installed in OsmoSamplers suspended inside the perforated and coat-ed casing and collars at depth.

Despite the use of a special unlatching tool and consider- 
able force to pull, push, and rotate, Expedition 327 failed to recover the old CORK deployed in Hole $1027 \mathrm{C}$ and to install a new, multi-level CORK in the deepened well. But as described in the next section, we were able to retrofit the Hole 1027C CORK with new pressure monitoring equip-ment in summer 2011, allowing this CORK to be used for crustal-scale, multi-directional, hydrogeologic experiments.

\section{R/V Atlantis and ROV Jason Expedition AT18-07}

During Atlantis Expedition AT18-07, we planned and accomplished the following goals.

- recovery of wellhead OsmoSampling systems deployed on pre-Expedition 327 CORKs, and deployment of new OsmoSampling systems on the new CORKs (for geochemical sampling and microbial growth experiments)

- downloading of long-term pressure data

- assessment of the condition and retrofitting the old CORK in Hole 1027C for pressure monitoring

- recovery and deployment of a long-term GeoMICROBE sled used for autonomous, large-volume fluid sampling and electrochemistry

- collection of large volumes of fluids from depth below the CORKs using a variety of pumping, sampling, and filtering systems

- deployment of an autonomous flowmeter on one of the Site U1362 CORKs, followed by opening of a ball valve to initiate a long-term, cross-hole flow experiment.

Of the planned operations, our ability to retrofit the CORK in Hole 1027C was the least certain when Expedition AT18-07 began. We did not know if we had damaged the CORK with the vigorous recovery attempt during Expedition 327 , and we rushed to design and built a series of tools to upgrade measurement and sampling capabilities in time for the subsequent expedition. The first necessary step was to extract a brass connector that was corroded in place on top of the wellhead (Fig. 3a). This eventually required using a customized harness hanging from below the ROV control vehicle Medea to pull out the connector. The old data logger was recovered at the same time, and it subsequently produced a complete pressure record from the previous two years (including the pressure response to nearby drilling during Expedition 327). We were then able to install a manifold insert with valves and fittings (Fig. 3b) and connect a new pressure logger for high-resolution monitoring. We were gratified to see almost immediate pressure equilibration in Hole $1027 \mathrm{C}$ following these operations, indicating that the
Hole 1027C CORK is sealed and providing reliable information on formation fluid pressure.

Pressure data downloaded from the new CORKs at Site U1362 show that they are functioning as intended. We can see different equilibrium pressures at different depths in Hole 1362A (which isolates distinct crustal intervals) and the setting of the swellable packer element at the base of casing in Hole U1362B (where we have continuous monitoring of the cased interval). OsmoSampler systems were recovered and replaced on older CORKs (Fig. 3c), and new systems were successfully deployed on new CORKs in Holes U1362A and U1362B (Fig. 3d, f). The GeoMICROBE sampling and electrochemical analysis sled was recovered from Hole U1301A (where it had been deployed) and redeployed on the CORK in Hole U1362B (Fig. 3d), where it will filter and collect large volumes of fluid and make electrochemical measurements over the next year. A new electromagnetic flow-meter was deployed above the large-diameter ball valve on the Hole U1362B wellhead (Fig. 3e); opening this valve resulted in a jet of warm $\left(\sim 63^{\circ} \mathrm{C}\right)$ hydrothermal fluid from the crust below. The flowmeter is recording fluid discharge hourly, and we will return to recover the tool and download the data in summer 2012. Fluid flow from Hole U1362B is expected to decrease with time over the next year, as the excess pressure in the sealed borehole is reduced. This record of time-varying flow, and the associated pressure responses in nearby observatories, will provide the first direct assessment of azimuthal hydrologic properties in the upper oceanic crust.

The inlets to fluid sampling lines were placed in the top of the "chimney" above the flowmeter after the valve was opened, and discharging fluids are being collected with geochemical and microbiological OsmoSamplers (Fig. 3g). Large volumes of high quality formation fluids were recovered from the new CORKs using pump and manifold systems in 2011 (Fig. 3h), and these CORKs will be visited again for fluid sampling in 2012. Samples recovered in 2011 are being analyzed to learn about formation chemistry and microbiology, and to assess the possible arrival of tracers pumped during the 24-hour injection experiment during IODP Expedition 327. The best tracer samples are likely to come from downhole samplers, which will be recovered over the next several years.

\section{Acknowledgements}

We thank the staff of Transocean and the U.S. Implementing Organization for IODP for their dedicated work in preparing for IODP Expedition 327. CORK servicing was skillfully supported by the crew, technicians and officers of the R/V Atlantis and ROV Jason. These experiments were supported by the U.S. National Science Foundation grants OCE-0727952 and OCE-1031808 (ATF), OCE-0727119 and OCE-1030061 (CGW), OCE-0726887 and OCE-1030350 (KB), OCE-0726563 and OCE-1031352 (JFC), 
and MCB-0604014 and OCE-0726838 (JPC). Additional support provided by the Gordon and Betty More Foundation (KJE and CGW). This is contribution \#111 from the Center for Dark Energy Biosphere Investigations.

\section{The IODP Expedition 327 Scientists}

A. Fisher, T. Tsuji, K. Petronotis, K. Becker, J. Cowen, J.M. Gautier, A. Haddad, J. Kane, S. Keske, M. Harris, S. Hulme, F. Ji, R. Masui, H. Miyamoto, S. Morvan, S. Mrozewski, B. Orcutt, L. Peart, B. Richardson, J. Rutter, B. Thiberge, C.G. Wheat, and D. Winslow

\section{Atlantis Expedition AT18-07 Shipboard Parties}

A. Fisher, K. Becker, J. Clark, S. Cooper, J. Cowen, K. Edwards, B. Glazer, S. Hulme, B. Orcutt, C.G. Wheat, A. Ausejo-Robador, R. Brennon, A. Gross, K. Hamner, C.-C. Hseih, S. Jungbluth, J. Kane, H.-T. Lin, G. Ramirez, J. Ringlein, A. Slovacek, and L. Strong

\section{References}

Becker, K., and Fisher, A.T., 2008. Borehole tests at multiple depths in 3.5-Ma seafloor resolve distinct hydrologic intervals. J. Geophys. Res., 113:B07105. doi:10.1029/2007JB005446

Coggon, R.M., Teagle, D.A.H., Smith-Duque, C.E., Alt, J.C., and Cooper, M.J., 2010. Reconstructing past seawater $\mathrm{Mg} / \mathrm{Ca}$ and $\mathrm{Sr} / \mathrm{Ca}$ from mid-ocean ridge flank calcium carbonate veins. Science, 327(5969):1114-1117. doi:10.1126/science. 1182252

Cowen, J.P., Giovannoni, S.J., Kenigm, F., Johnson, H.P., Butterfield, D., Rappé, M.S., Hutnak, M., and Lam, P., 2003. Fluids from aging ocean crust that support microbial life. Science, 299:120-123. doi:10.1126/science. 1075653

Davis, E.E., Chapman, D.S., Mottl, M.J., Bentkowski, W.J., Dadey, K., Forster, C., Harris, R., Nagihara, S., Rohr, K., Wheat, G., and Whiticar, M., 1992. FlankFlux: An experiment to study the nature of hydrothermal circulation in young oceanic crust. Can. J. Earth Sci., 29(5):925-952.

Davis, E.E., Chapman, D.S., Wang, K., Villinger, H., Fisher, A.T., Robinson, S.W., Grigel, J., Pribnow, D., Stein, J., and Becker, K., 1999. Regional heat-flow variations across the sedimented Juan de Fuca Ridge eastern flank: Constraints on lithospheric cooling and lateral hydrothermal heat transport. J. Geophys. Res., 104(B8):17675-17688.

Davis, E.E., Fisher, A.T., and Firth, J., 1997. Proc. ODP, Init. Repts. 168, College Station, TX (Ocean Drilling Program).

Elderfield, H., Wheat, C.G., Mottl, M.J., Monnin, C., and Spiro, B., 1999. Fluid and geochemical transport through oceanic crust: A transect across the eastern flank of the Juan de Fuca Ridge. Earth Planet. Sci. Lett., 172:151-165. doi:10.1016/S0012-821X(99)00191-0.

Fisher, A.T., Cowen, J., Wheat, C.G., and Clark,J.F., 2011a. Preparation and injection of fluid tracers during IODP Expedition 327, eastern flank of Juan de Fuca Ridge. In Fisher, A.T., Tsuji, T., and Petronotis, K., Proc. IODP, 327: Tokyo (Integrated Ocean Drilling Program Management International, Inc.). doi:10.2204/iodp.proc.2327.2108.2011

Fisher, A.T., Davis, E.E., and Becker, K., 2008. Borehole-to-borehole hydrologic response across $2.4 \mathrm{~km}$ in the upper oceanic crust: implications for crustal-scale properties. J. Geophys. Res., 113:B07106. doi:10.1029/2007JB005447

Fisher, A.T., Davis, E.E., Hutnak, M., Spiess, V., Zühlsdorff, L., Cherkaoui, A., Christiansen, L., et al., 2003. Hydrothermal recharge and discharge across $50 \mathrm{~km}$ guided by seamounts on a young ridge flank. Nature, 421:618-621. doi:10.1038/ nature 01352

Fisher, A.T., Tsuji, T., and Petronotis, K., 2011b. Proc. IODP, 327: Tokyo (Integrated Ocean Drilling Program Management International, Inc.). doi:10.2204/iodp.proc.327.2011

Fisher, A.T., Urabe, T., and Klaus, A., 2005a. Proc. IODP, 301: Washington, DC (Integrated Ocean Program Management International, Inc.). doi:10.2204/iodp.proc.2301.2005 pp

Fisher, A.T., Wheat, C.G., Becker, K., Cowen, J., Orcutt, B., Hulme, S., Inderbitzen, K., et al., 2011c. Design, deployment, and status of borehole observatory systems used for single-hole and cross-hole experiments, IODP Expedition 327, eastern flank of the Juan de Fuca Ridge. In Fisher, A.T., Tsuji, T., and Petronotis, K., Proc. IODP, 327: Tokyo(Integrated Ocean Drilling Program Management International, Inc.). doi:10.2204/iodp.proc.327.107.2011

Fisher, A.T., Wheat, C.G., Becker, K., Davis, E.E., Jannasch, H., Schroeder, D., Dixon, R., et al., 2005b. Scientific and technical design and deployment of long-term, subseafloor observatories for hydrogeologic and related experiments, IODP Expedition 301, eastern flank of Juan de Fuca Ridge. In Fisher, A.T., Urabe, T., and Klaus, A., Proc. IODP, 301: Washington, DC (Integrated Ocean Drilling Program Management International, Inc.). doi:10.2204/iodp. proc.2301.2103.2005

Huber, J.A., Butterfield, D.A., Johnson, H.P., and Baross, J.A., 2006. Microbial life in ridge flank crustal fluids. Env. Microbiol., 88:88-99. doi:10.1111/j.1462-2920.2005.00872.x

Hutnak, M., Fisher, A.T., Zühlsdorff, L., Spiess, V., Stauffer, P., and Gable, C.W., 2006. Hydrothermal recharge and discharge guided by basement outcrops on 0.7-3.6 Ma seafloor east of the Juan de Fuca Ridge: Observations and numerical models. Geochem. Geophys. Geosys., 7:Q07O02. doi:10.1029/ 2006GC001242

Johnson, H.P., and Pruis, M.J., 2003. Fluxes of fluid and heat from the oceanic crustal reservoir. Earth Planet. Sci. Lett., 216:565-574. doi:10.1016/S0012-821X(03)00545-4

Mottl, M., 2003. Partitioning of energy and mass fluxes between midocean ridge axes and flanks at high and low temperature. In Halbach, P., Tunnicliffe, V., and Hein, J. (Eds.), Energy and Mass Transfer in Submarine Hydrothermal Systems: Berlin (Dahlem University Press), 271-286.

Orcutt, B.N., Bach, W., Becker, K., Fisher, A.T., Hulme, S., Toner, B.M., Wheat, C.G., and Edwards, K.J., 2010a. Microbial borehole observatories deployed within the oceanic crust: Design considerations and initial results from long-term colonization experiments. [Invited paper presented at American Geophysical Union 2010 Fall Meeting, San Francisco, CA, 12-17 December 2010]. doi:10.1080/ 


\section{2}

Orcutt, B.N., Wheat, C.G. and Edwards, K., 2010b. Subseafloor ocean crust microbial observatories: Development of FLOCS (FLow-through Osmo Colonization System) and evaluation of borehole construction materials. Geomicrobiol. J., 27:143-157. doi:10.1080/01490450903456772

Parsons, B., and Sclater, J.G., 1977. An analysis of the variation of ocean floor bathymetry and heat flow with age. J. Geophys. Res., 82:803-829. doi:10.1029/JB082i005p00803

Smith, A., Popa, R., Fisk, M., Nielsen, M., Wheat, C.G., Jannasch, H., Fisher, A.T., Becker, K., Sievert, S., and Flores, G., in review. A novel method for studying in situ microbial colonization of igneous minerals and glasses in ocean crust. Geochem. Geophys. Geosys.

Stein, J.S., and Fisher, A.T., 2003. Observations and models of lateral hydrothermal circulation on a young ridge flank: Numerical evaluation of thermal and chemical constraints. Geochem. Geophys. Geosys., 4:1026. doi:10.1029/2002GC000415

Underwood, M., Hoke, K.D., Fisher, A.T., Giambalvo, E.G., Davis, E.E., and Zühlsdorff, L., 2005. Provenance, stratigraphic architecture, and hydrogeologic effects of turbidites in northwestern Cascadia Basin, Pacific Ocean. J. Sediment. Res., 75(1):149-164. doi:10.2110/jsr.2005.012

Walker, B.D., McCarthy, M.D., Fisher, A.T., and Guilderson, T.P., 2007. Dissolved inorganic carbon isotopic composition of low-temperature axial and ridge-flank hydrothermal fluids of the Juan de Fuca Ridge. Mar. Chem., 108(1-2):123-136. doi:10.1016/j.marchem.2007.1011.1002

Wheat, C.G., Elderfield, H., Mottl, M.J., and Monnin, C., 2000. Chemical composition of basement fluids within an oceanic ridge flank: Implications for along-strike and across-strike hydrothermal circulation. J. Geophys. Res., 105(B6):13437-13447. doi:10.1029/2000JB900070

Wheat, C.G., Jannasch, H.W., Fisher, A.T., Becker, K., Sharkey, J., and Hulme, S.M., 2010. Subseafloor seawater-basalt-microbe reactions: Continuous sampling of borehole fluids in a ridge flank environment. Geochem. Geophys. Geosys., 11:Q07011. doi:10.1029/2010GC00305

Wheat, C.G., Jannasch, H.W., Kastner, M., Hulme, S., Cowen, J., Edwards, K., Orcutt, B., and Glazer, B., in review. Fluid sampling from oceanic borehole observatories: Design and methods for CORK activities (1990-2010). In Fisher, A.T., Tsuji, T., and Petronotis, K., Proc. IODP, 327: Washington, DC (Integrated Ocean Drilling Program Management International, Inc.). doi:10.2204/iodp.proc.327.109.2011

Wheat, C.G., Jannasch, H.W., Kastner, M., Plant, J.N., DeCarlo, E., and Lebon, G.T., 2004a. Venting formation fluids from deepsea boreholes in a ridge flank setting: ODP Sites 1025 and 1026. Geochem. Geophys. Geosys., 5(8):Q08007. doi:08010. 01029/02004GC000710.

Wheat, C.G., McManus, J., Mottl, M., and Giambalvo, E.G., 2003. Oceanic phosphorus imbalance: Magnitude of the midocean ridge flank hydrothermal sink. Geophys. Res. Lett., 30:1895. doi:10.1029/2003GL017318

Wheat, C.G., Mottl, M.J., Fisher, A.T., Kadko, D., Davis, E.E., and Baker, E., 2004b. Heat flow through a basaltic outcrop on a sedimented young ridge flank. Geochem. Geophys. Geosys., 5(12):Q12006. doi:10.1029/2004GC000700

\section{Authors}

Andrew T. Fisher, Earth and Planetary Sciences Department and Institute for Geophysics and Planetary Physics, University of California at Santa Cruz, 1156 High Street, Santa Cruz, CA 95064, U.S.A., e-mail: afisher@ucsc. edu.

Takeshi Tsuji, Graduate School of Engineering, Kyoto University, C1-1-110 Kyotodaigaku-Katsura, Nishikyo-ku, Kyoto 615-8540, Japan.

Katerina Petronotis, Integrated Ocean Drilling Program, Texas A\&M University, 1000 Discovery Drive, College Station, TX 77845-9547, U.S.A.

C. Geoff Wheat, Global Undersea Research Unit, P.O. Box 475, Moss Landing, CA 95039, U.S.A.

Keir Becker, Rosenstiel School of Marine and Atmospheric Science, University of Miami, Division of Marine Geology and Geophysics, 4600 Rickenbacker Causeway, Miami, FL 33149-1098, U.S.A.

Jordan F. Clark, Department of Earth Science and Program of Environmental Studies, University of California Santa Barbara, 1006 Webb Hall, Santa Barbara, CA 93106-9630, U.S.A.

James Cowen, Department of Oceanography, University of Hawaii at Manoa, 1000 Pope Road, Marine Sciences Building, Honolulu, HI 96822, U.S.A.

Katrina Edwards, Center for Earth Sciences, University of Southern California, 3651 Trousdale Parkway, Los Angeles, CA 90089-0740, U.S.A.

Hans Jannasch, Monterey Bay Aquarium Research Institute, 7700 Sandholt Road, Moss Landing, CA, 95039, U.S.A.

and the IODP Expedition 327 and Atlantis Expedition AT18-07 Shipboard Parties

\section{Photo Credits}

Photographs were provided courtesy of Andrew Fisher (UCSC), the AT18-07 Shipboard Party, and the U.S. National Deep Submergence Facility (WHOI) 